\title{
PENERAPAN METODA FUZZY DALAM KLASIFIKASI LAHAN KRITIS BERBASIS HYDRAULIC RESPONSE UNIT (HRU) SUBDAS CISANGKUY
}

\author{
Implementation Of Fuzzy Method In Critical Land Classification Based On Hydraulic \\ Response Unit (HRU) Cisangkuy Watershed Area.
}

\author{
Bambang Setio Budianto ${ }^{a}$, Muhammad Yanuar Jarwadi Purwanto ${ }^{\mathrm{b}}$, Widiatmaka ${ }^{\mathrm{c}}$, Lilik Budi Prasetyo ${ }^{\mathrm{d}}$ \\ ${ }^{a}$ Program Studi Pengelolaan Sumberdaya Alam dan Lingkungan, Sekolah Pascasarjana, Institut Pertanian Bogor, \\ Kampus IPB Baranangsiang, Bogor-bs_budianto@yahoo.co.id \\ ${ }^{b}$ Departemen Teknik Sipil dan Lingkungan, Fakultas Teknologi Pertanian, Institut Pertanian Bogor, Gedung \\ Dept SIL-IPB, Kampus IPB Dramaga Bogor 16680 Telp. (0251) 8627225 \\ ${ }^{c}$ Departemen Ilmu Tanah dan Sumberdaya Lahan, Fakultas Pertanian, Institut Pertanian Bogor, Kampus IPB \\ Darmaga, Bogor 16680 \\ ${ }^{d}$ Departemen Konservasi Sumberdaya Hutan dan Ekowisata, Fakultas Kehutanan, Institut Pertanian Bogor, \\ Kampus IPB Dramaga, Bogor 16680
}

\begin{abstract}
Various natural disasters, such as floods and landslides, are often associated with extreme weather conditions, especially rainfall, where in fact the possibility of such a disaster will be smaller if the carrying capacity of the land is still good. The decrease of land carrying capacity is often due to land use change, so that the land is not capable to perform it functions and is categorized as critical land. The decline in land carrying capacity will affect other resources, especially water resources. Anticipatory measures of natural disasters such as floods and landslides can perfectly prepared if information regarding land conditions, including land criticality, are available in detail and up to date. The classification and mapping of land criticality becomes an important component in the preparation of land rehabilitation and natural disaster prevention plans including setting the priority actions. The Minister of Forestry Regulation no P.32 / Menhut-II / 2009 concerning Procedures for Preparation of Forest and Watershed Technical Rehabilitation Plan was use as criteria for land classification and both Fuzzy and Crisp calculation methods were applied to calculate the final score. Different classification result was found in 23 HURL and comparing to actual the condition, the Fuzzy method gives more accurate result than Crisp method.
\end{abstract}

Keywords: Lahan Kritis, SIG, Fuzzy, Hydraulic Response Unit, HRUs

(Diterima: 14-06-2017; Disetujui: 14-08-2017)

\section{Pendahuluan}

\subsection{Latar Belakang}

Dalam dekade terakhir ini, frekuensi dan intensitas terjadinya bencana alam yang berkatian dengan lahan seperti longsor dan banjir semakin meningkat. Peningkatan intensitas dan frekuensi bencana alam lebih sering dikaitkan dengan perubahan iklim, khususnya cuaca ekstrim. Meskipun bencana alam tersebut terjadi pada saat terjadinya cuaca ekstrim, bukan berarti cuaca ekstrim merupakan satu-satunya penyebab terjadinya bencana. Bencana longsor dan banjir tidak akan terjadi apabila daya dukung lahan masih baik.

Antisipasi terjadinya bencana alam khususnya yang berkaitan dengan sumber daya lahan dilakukan dengan menjaga, meningkatkan, dan memperbaiki daya dukung lahan. Peningkatan dan perbaikan kondisi lahan akan sangat bergantung pada komponen-komponen yang berpengaruh terhadap kondisi lahan seperti pola penutupan lahan, kemiringan, tingkat erosi, dan tingkat manajemen lahan yang dilakukan. Dengan kata lain informasi tentang komponen-komponen tersebut mutlak diperlukan dalam program perbaikan daya dukung lahan.
Berbagai metoda pengumpulan dan pengolahan data telah diterapkan dan dikembangkan dalam rangka pengelolaan sumber daya lahan, terutama pada Daerah Aliran Sungai (DAS). Penggunanaan citra satelit dalam pengelolaan sumberdaya alam khususnya sumber daya lahan telah dibuktikan manfaatnya (Baharudin, 2010; Purwaamijaya, 2013; Prasetyo et al., 2013). Pemanfaatan citra satelit dalam pengelolaan lahan masih harus dikembangkan untuk mempercepat proses serta meningkatkan akurasinya.

Pada penelitian ini evaluasi terhadap kekritisan lahan dilakukan berbasis Hydraulic Response Unit (HRU) yang dihasilkan dari perangkat lunak Soil and Water Analyisis Tool (SWAT). Evaluasi berbasis HRU selain akan mempercepat proses evaluasi, karena untuk berbagai area yang mempunyai karakteristik hidrolis yang sama perhitungan akan dilakukan satu kali, juga akan sekaligus memperkecil kebutuhan memori pada perangkat keras, sehingga tidak memerlukan perangkat keras dengan spesifikasi khusus. Penggunaan perangkat lunak SWAT dalam pembentukan HRU akan memperkecil kesalahan yang bersumber pada manusia. Selain menghasilkan HRU, simulasi SWAT akan memberikan besaran erosi yang merupakan salah satu kriteria pentapan tingkat kekritisan lahan. Kendala 
penggunaan perangkat lunak SWAT adalah diperlukannya beberapa data tambahan, serta operasional perangkat lunak tersebut tidak mudah.

Peraturan Menteri Kehutanan RI no P.32/MenhutII/2009 membedakan tingkat kekritisan lahan berdasarkan nilai yang dihitung berdasarkan kelas dan bobot dari setiap kriteria penilaian. Pada umumnya perhitungan nilai kekritisan lahan dilakukan menerapkan himpunan tegas (Crisp). Perhitungan dengan himpunan tegas sangat mudah dilakukan, namun pada kenyataannya seringkali dijumpai situasi dimana dua kondisi riil dilapangan nampak "mirip" namun dari hasil perhitungan menunjukkan perbedaan tingkat kekritisan, sebaliknya kadang dijumpai dua kondisi yang nampak berbeda tetapi hasil perhitungan menunjukkan tingkat kekritisan yang sama. Dalam kaitan tersebut metoda himpunan Fuzzy akan diterapkan dengan harapan dapat memberikan gambaran yang lebih selaras antara hasil perhitungan dengan kondisi riil di lapangan.

\subsection{Tujuan Penelitian}

Tujuan penelitian ini adalah:

1. Melakukan klasifikasi lahan kritis Kawasan Lindung SubDAS Cisangkuy berbasis HRU, dengan metoda Fuzzy.

2. Membadingkan hasil klasifikasi lahan khritis berdasarkan metoda fuzzy dengan metoda Himpunan tegas (crips).

\section{Metode}

\subsection{Waktu dan Lokasi Penelitian}

Penelitian dilakukan di Sub-DAS Cisangkuy, Kabupaten Bandung, Provinsi Jawa Barat, area penelitian mencakup hulu sungai Cisangkuy hingga outlet Pos duga Kamasan Desa Padamukti Sukaresmi, dengan koordinat: 7²'46" LS-107³4'40" BT (Gambar 1). Sub-DAS Cisangkuy dipilih karena sub-DAS ini memberikan kontribusi yang besar terhadap terjadinya banjir di daerah Bandung Selatan. Sub-Das Cisangkuy merupakan bagian dari DAS Citarum yang termasuk yang menurut Hasan et al. (2011) termasuk dalam DAS yang tidak aman, dan menurut Anik (2007) Sub-DAS Cisangkuy merupakan bagian dari 13 SubDAS di DAS Citarum dengan kategori sangat kritis. Pesatnya perubahan tataguna lahan di sub-DAS ini diduga akan meningkatkan luasan lahan kritis, sehingga penelitian di wilayah ini diharapkan dapat memberikan kontribusi terhadap upaya pemulihan lahan kritis.

Metode yang digunakan dalam penelitian ini adalah metode studi pustaka (desk study) berupa analisis peta citra dan data sekunder dari instansi terkait, baik dari BPDAS Citarum Ciliwung, BBWS Citarum, dan Dinas PSDA Jawa Barat.

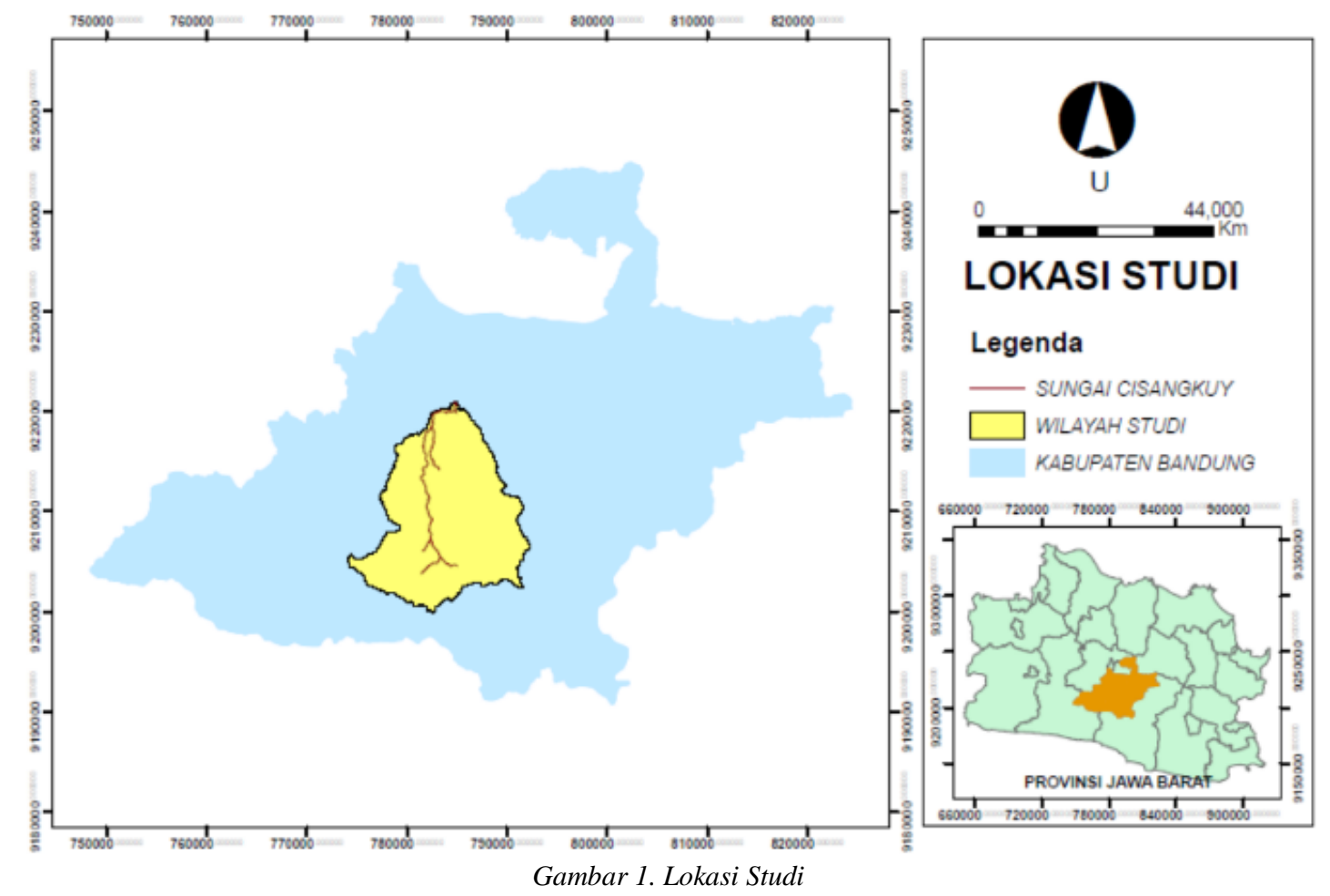

\subsection{Analisa Data}

Klasifikasi kekritisan lahan dilakukan untuk setiap HRU dengan mengacu pada Peraturan Menteri Kehutanan RI no P.32/Menhut-II/2009 yang mendasarkan penilaian terhadap 4 komponen penilaian yaitu penutupan lahan, kemiringan lereng, tingkat erosi, dan magemen pengelolaan lahan. Data penutupan lahan diperoleh melalui pengolahan citra SPOT6, kemiringan lereng diperoleh dari Data DEM (SRTM 30 × 30 m), besaran erosi diperoleh melalui simulasi hidrolis dengan perangkat lunak SWAT, sedangkan tingkat manajemen lahan ditetapkan berdasarkan laporan program BPDAS Citarum Ciliwung. 
Pembentukan HRU dan perhitungan tingkat erosi dilakukan menggunakan perangkat lunak SWAT dengan data input sebagai berikut:

1. Data DEM (SRTM 30 × $30 \mathrm{~m})$

2. Peta Tutupan Lahan diolah dari peta Citra SPOT 6

3. Peta Tanah skala 1 : 100000 (BPDAS Citarum Ciliwung 2015)

4. Peta Jaringan Sungai 1:250,000

5. Data Iklim

a. Data Curah Hujan (stasiun Ciherang, Stasiun Bandung, Stasiun Cileunca, Cibereum, Kertamanah, Cipanas) tahun 2005-2014

b. Data Suhu (stasiun Bandung) tahun 2005-2014

c. Data Kecepatan angin (stasiun Bandung) tahun 2005-2014 d. Data Kelembaban udara (stasiun Bandung) tahun 2005-2014

e. Data Radiasi Matahari (stasiun Bandung ) tahun 2005-2014

6. Data Debit Aktual (stasiun Kamasan) tahun 2005 2014.

Dari hasil simulasi SWAT dilakukan klasifikasi kekritisan lahan menggunakan metoda Crisp dan Fuzzy Baik perhitungan dengan metoda Crisp maupun Fuzzy dilakukan dengan mengacu pada kriteria seperti disajikan pada Tabel 1 dan Tabel 2. Pada perhitungan metoda Crisp dilakukan dengan persamaan sebagai berikut (Persamaan 1):

$$
\text { Nilai }=\sum \text { bobot } \mathrm{x} \text { Skor }
$$

Tabel 1. Kriteria Klasifikasi Lahan Kritis

\begin{tabular}{|c|c|c|c|c|c|}
\hline No & $\begin{array}{l}\text { Kriteria } \\
(\% \text { Bobot })\end{array}$ & Kelas & Besaran / Deskripsi & Skor & Keterangan \\
\hline \multirow{5}{*}{1} & \multirow{5}{*}{$\begin{array}{l}\text { Penutupan } \\
(50)\end{array}$} & Sangat baik & $>80 \%$ & 5 & \multirow{5}{*}{$\begin{array}{l}\text { Dihitung berdasar- } \\
\text { kan presentase pe- } \\
\text { nutupan tajuk }\end{array}$} \\
\hline & & Baik & $61-80 \%$ & 4 & \\
\hline & & Sedang & $41-60 \%$ & 3 & \\
\hline & & Buruk & $21-40 \%$ & 2 & \\
\hline & & Sangat buruk & $\leq 20 \%$ & 1 & \\
\hline \multirow{5}{*}{2} & \multirow{5}{*}{ Lereng (20) } & Datar & $<8 \%$ & 5 & \\
\hline & & Landai & $8-15 \%$ & 4 & \\
\hline & & Agak curam & $16-25 \%$ & 3 & \\
\hline & & Curam & $26-40 \%$ & 2 & \\
\hline & & Sangat curam & $\geq 40 \%$ & 1 & \\
\hline \multirow{5}{*}{3} & \multirow{5}{*}{$\begin{array}{l}\text { Erosi (ton/ha/tahun) } \\
\text { (20) }\end{array}$} & Sangat ringan & $<15$ & 5 & \\
\hline & & Ringan & $15-60$ & 4 & \\
\hline & & Sedang & $61-180$ & 3 & \\
\hline & & Berat & $181-480$ & 2 & \\
\hline & & Sangat berat & $>480$ & 1 & \\
\hline \multirow{4}{*}{4} & \multirow{4}{*}{ Manajemen (10) } & Baik & Lengkap & 5 & \multirow{4}{*}{$\begin{array}{l}\text { Tata batas } \\
\text { pengamanan } \\
\text { pengawasan } \\
\text { penyuluhan } \\
\text { aksanakan }\end{array}$} \\
\hline & & Sedang & Tidak lengkap & 3 & \\
\hline & & & & & \\
\hline & & Buruk & Tidak ada & 1 & \\
\hline
\end{tabular}

Tabel 2. Klasifikasi kekritisan lahan di Kawasan Hutan Lindung

\begin{tabular}{clc}
\hline No. & Tingkat Kekritisan Lahan & Besarnya Nilai \\
\hline 1. & Sangat kritis & $120-180$ \\
2. & Kritis & $181-270$ \\
3. & Agak kritis & $271-360$ \\
4. & Potensial kritis & $361-450$ \\
5. & Tidak kritis & $451-500$ \\
\hline
\end{tabular}

Berdasarkan kriteria tersebut disusun keanggotaan himpunan Fuzzy untuk masing komponen penilaian, meskipun untuk komponen manajemen, dimana diterapkan skala kualitatif, himpunan tegas (crisp) lebih tepat untuk diterapkan. Dengan menetapkan nilai tengah sebagai nilai keanggotaan penuh maka diperoleh diagram keanggotaan fuzzy seperti disajikan pada Gambar 2.

Klasifikasi lahan kritis dengan Metoda Fuzzy Sugeno dipilih karena luaran dari metode tersebut berupa nilai tegas (Kusumadewi dan Purnomo, 2010), sehinggga langsung dapat digunakan dalam klasifikasi kekritisan lahan. Perhitungan dengan metoda Fuzzy Sugeno dipandang relative lebih mudah dibandingkan dengan metoda fuzzy lainnya. Kastaman et al. (2007) dalam penelitiannya menyimpulkan bahwa metoda fuzzy mampu mengatasi ketidakpastian dalam klasifikasi lahan kritis, namun memerlukan perangkat lunak dan perangkat keras yang canggih. Dengan menerapkan metoda fuzzy Sugeno maka kendala perangkat lunak dan perangkat keras dapat diatasi megingat metoda ini dapat dilakukan dengan perangkat lunak yang umum digunakan seperti EXCEL dan ARCGIS, baik melalui langkah biasa maupun melalui Macro. Adapun persamaan yang digunakan adalah (Persamaan 2):

$$
Z=\frac{\propto_{i} z_{i}+\cdots+\propto_{n} z_{n}}{\propto_{i}+\cdots+\propto_{n}}
$$

dimana:

$\mathrm{Z}$ = Nilai

$\propto_{i}=\min \left(\mu_{\text {tutupan }}, \mu_{\text {lereng }}, \mu_{\text {erosi }}, \mu_{\text {manajemen }}\right)$

$\mathrm{z}_{\mathrm{i}}=$ nilai solusi ke $\mathrm{i}$

$\mu=$ keanggotaan himpunan Fuzzy 

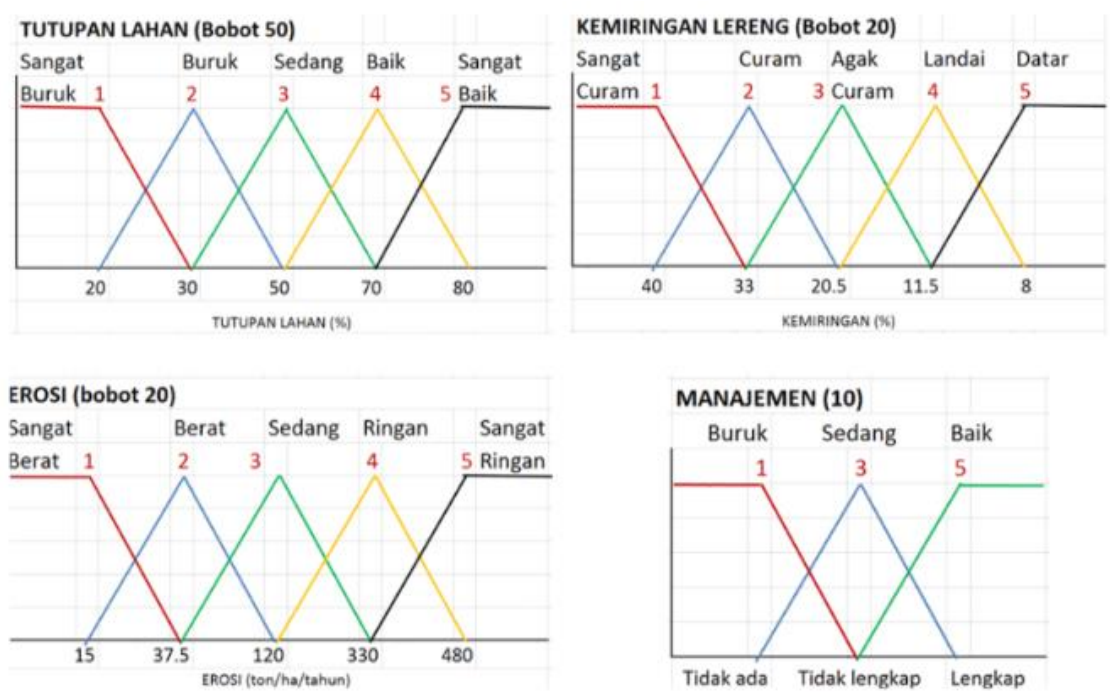

Gambar 2. Diagram Himpunan Fuzzy Lahan Kritis

\section{Hasil dan Pembahasan}

Secara keseluruhan wilayah penelitian mencakup area dengan luas total $13096.31 \mathrm{Ha}$, dengan pola penggunaan lahan, kelas kemiringan lereng seperti disajikan pada Gambar 3 dan Gambar 4, sedangkan kondisi tanah di daerah penelitian disajikan pada Gambar 5 dan Tabel 3.

Dari hasil simulasi SWAT diperoleh 141 HRU, dengan tingkat erosi bervariasi antara 1,682 ton/ha/tahun ton/ha/tahun sampai 879,837 toh/ha/tahun. Perhitungan dan klasifikasi lahan dilakukan sesuai dengan jumlah HRU yaitu sebanyak 141 kali, jauh lebih sedikit dibandingkan dengan jumlah petak lahan hasil overlay peta Tutupan Lahan, Kemiringan Lereng, dan Jenis Tanah. Klasifikasi berbasis HRU, selain lebih efisien, hasilnya akan lebih mudah digunakan dalam penyusunan prioritas penanggulangan lahan kritis $\mathrm{Hal}$ yang sama disimpulkan pula oleh Kumar dan Mishra (2015).

Hasil klasifikasi lahan menggunakan metoda Fuzzy menunjukan bahwa 15 HRU termasuk klasifikasi Sangat Kritis, 55 HRU Kritis, 38 HRU Agak Kritis, dan $32 \mathrm{HRU}$ potensial kritis. Hasil klasifikasi lahan menggunakan metoda Crisp menunjukan bahwa 18 HRU termasuk klasifikasi Sangat Kritis, 54 HRU Kritis, 36 HRU Agak Kritis, dan 32 HRU potensial kritis. Hasil Klasifikasi lahan kritis dengan metoda Fuzzy dan Crips secara berturut-turut disajikan pada Gambar 6 dan Gambar 7.
Perbandingan hasil klasifikasi kekritisan lahan dengan metoda Fuzzy dan metoda Crisp menunjukkan perbedaan klasifikasi pada $23 \mathrm{HRU}$. Gambar 8 dan Tabel 5 menunjukkan perbedaan hasil klasifikasi yang dapat diuraikan sebagai berikut:

- Dari 15 HRU yang pada metoda Fuzzy dikategorikan sebagai sangat kritis, 4 pada metoda Crips diantaranya dikategorikan sebagai kritis.

- Dari 55 HRU yang pada metoda Fuzzy dikategorikan sebagai kritis, pada metoda Crips 7 diantaranya dikategorikan sebagai sangat kritis, dan $4 \mathrm{HRU}$ kategorikan agak kritis.

- Dari 38 HRU yang pada metoda Fuzzy dikategorikan sebagai agak kritis, pada metoda Crips 2 diantaranya dikategorikan sebagai kritis, dan 3 HRU kategorikan potensial kritis.

- Dari 32 HRU yang pada metoda Fuzzy dikategorikan sebagai potensial kritis, pada metoda Crips 3 diantaranya dikategorikan sebagai agak kritis.

Sejalan dengan kesimpulan Hall et al. (1992), klasifikasi lahan kritis dengan metoda Fuzzy Sugeno menghasilkan nilai kekritisan lahan secara lebih detail, sehingga informasi yang diberikan lebih banyak dan akurat. Metoda Fuzzy memberikan nilai keanggotaan himpunan dari 0 hingga 1 untuk setiap kriteria penilaian, sehingga perbedaan kondisi lapangan yang kecil dapat diperhitungkan. Dengan kata lain metoda Fuzzy mampu membedakan lahan memiliki perbedaan yang bergradasi (Keshavarzi et al. 2010). 

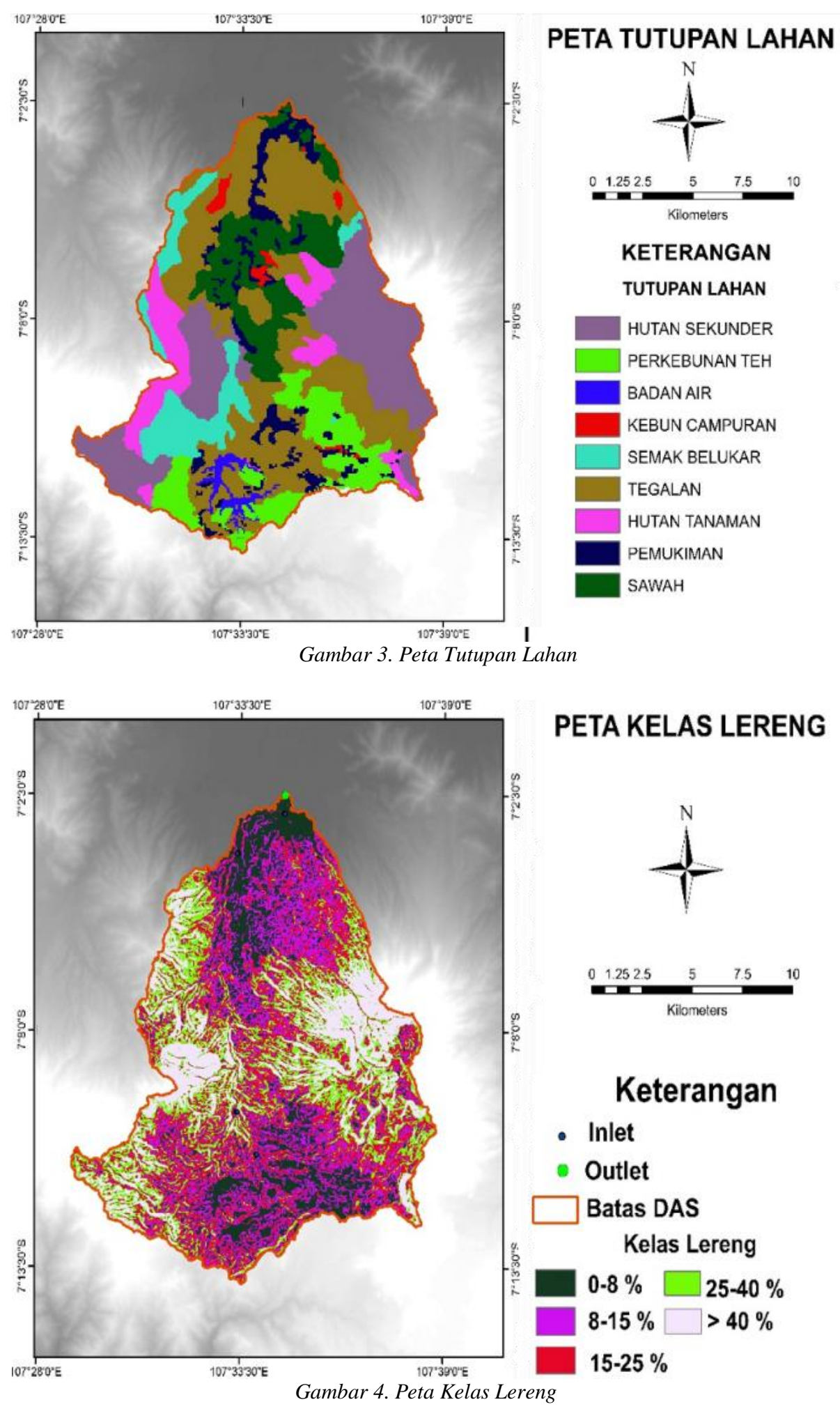


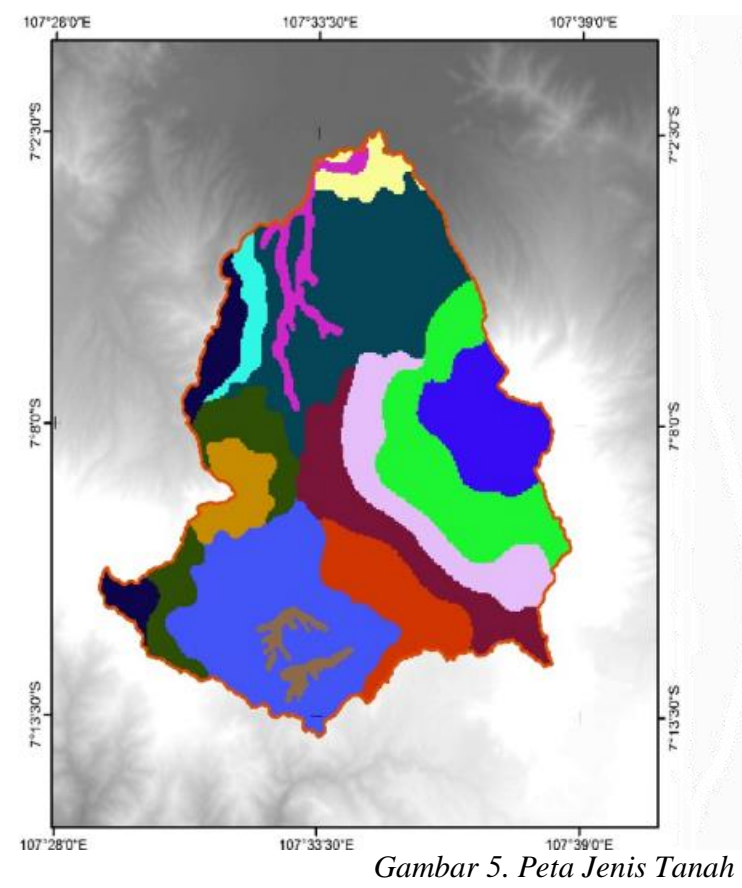

PETA JENIS TANAH

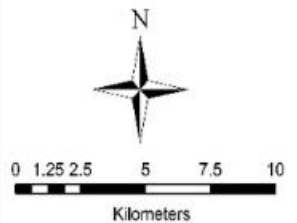

KETERANGAN

JENIS TANAH

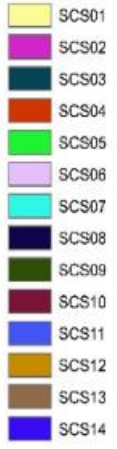

Tabel 3. Jenis Tanah SubDAS Cisangkuy

\begin{tabular}{llc}
\hline \multicolumn{1}{c}{ Jenis Tanah } & Kode & $\begin{array}{c}\text { Luas } \\
\text { (ha) }\end{array}$ \\
\hline $\begin{array}{l}\text { Typic Tropaquepts, Vertic Tropaquepts, } \\
\text { Vertic Eutric }\end{array}$ & SCS01 & 462 \\
$\begin{array}{l}\text { Typic Eutropepts, Typic Tropaquepts } \\
\text { Typic Humitropepts, Aquic Eutropepts, }\end{array}$ & SCS02 & 671 \\
Typic Eutropepts & & 4024 \\
Thaptic Hapludands, Euretic Hapludands & SCS04 & 1454 \\
Typic Hapludolls, Andic Haplodolls, & SCS05 & 2498 \\
Oxic Dystropepts & & \\
Typic Hapludolls, Typic Eutropepts & SCS06 & 1646 \\
Typyc Hapludalfs, Typic Eutropepts & SCS07 & 444 \\
Typic Humitropepts, Typic Eutropepts & SCS08 & 843 \\
Eutric Hapludands, Typic Kandiudalfs & SCS09 & 1386 \\
$\begin{array}{l}\text { Eutric Hapludands } \\
\text { Typic Melanudands, Eitric Hapludands }\end{array}$ & SCS10 & 1737 \\
Typic Hapludands, Eutric Hapludands & SCS11 & 3625 \\
Waduk & SCS12 & 724 \\
Oxic Humitropeps, Typic Eutropepts & SCS14 & 366 \\
\hline
\end{tabular}

Tabel 4. Klasifikasi Lahan Kritis Dengan Metoda Fuzzy dan Metoda

\begin{tabular}{lcc}
\multicolumn{3}{c}{ Crisp. } \\
\hline \multicolumn{1}{c}{ Status } & Fuzzy (Hru) & Crisp (Hru) \\
\hline S Kritis & 79 & 110 \\
Kritis & 321 & 325 \\
Agak Kritis & 139 & 126 \\
Pot Kritis & 133 & 111 \\
Tidak Kritis & 48 & 48 \\
\hline
\end{tabular}

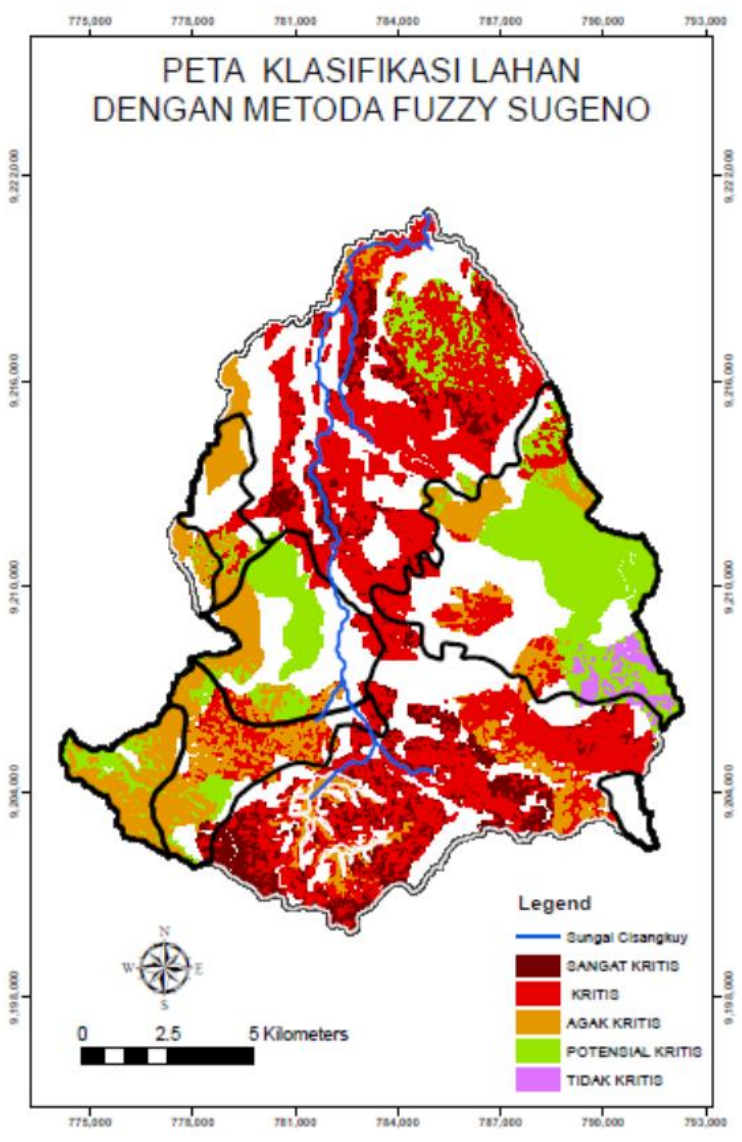

Gambar 6. Peta Klasifikasi Lahan Kritis Dengan Motoda Fuzzy 


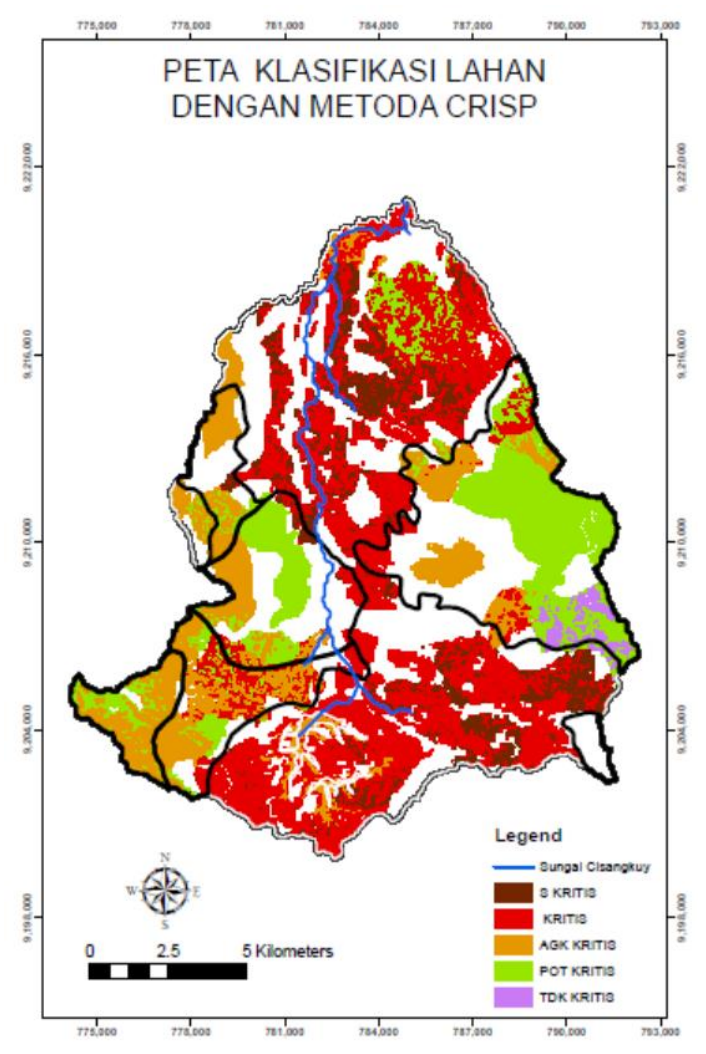

Gambar 7. Peta Klasifikasi Lahan Kritis Dengan Motoda Crisp

Tabel 5. Matriks Perbedaan Klasifikasi Lahan Metoda Fuzzy dan Metoda Crisp

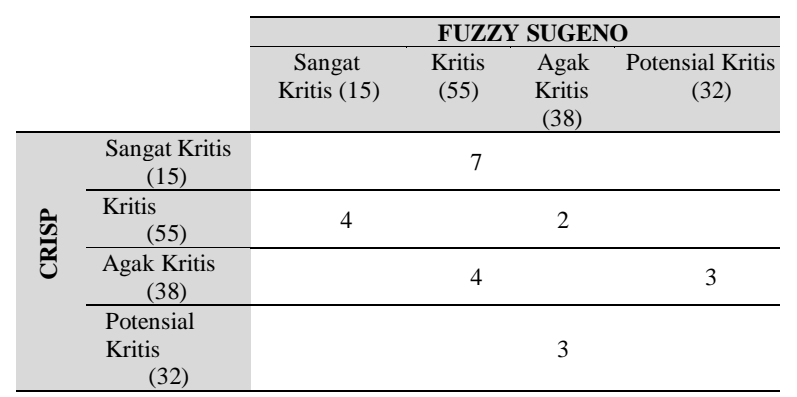

\section{Kesimpulan}

Hasil penelitian menunjukkan bahwa klasifikasi lahan kritis dengan metoda Fuzzy mampu menggambarkan kondisi lapangan secara lebih akurat dibandingkan denga metoda Crips. Proses klasifikasi Lahan kritis dengan metoda Fuzzy berbasis HRU dapat dilakukan secara cepat menggunakan perangkat komputer standar.

\section{Daftar Pustaka}

[1] Anik, S, 2007. Evaluasi Kekritisan Lahan Daerah Aliran Sungai. Jurnal Presipitasi. 2(1), pp. 8-14.

[2] Baharuddin, 2010. Pemanfaatan Inderaja Dan Sistem Informasi Geografis (SIG) Dalam Inventarisasi Lahan Kritis Di Kabupaten Kolaka Utara. Jurnal Perenial. 6(2), pp. 83-89.

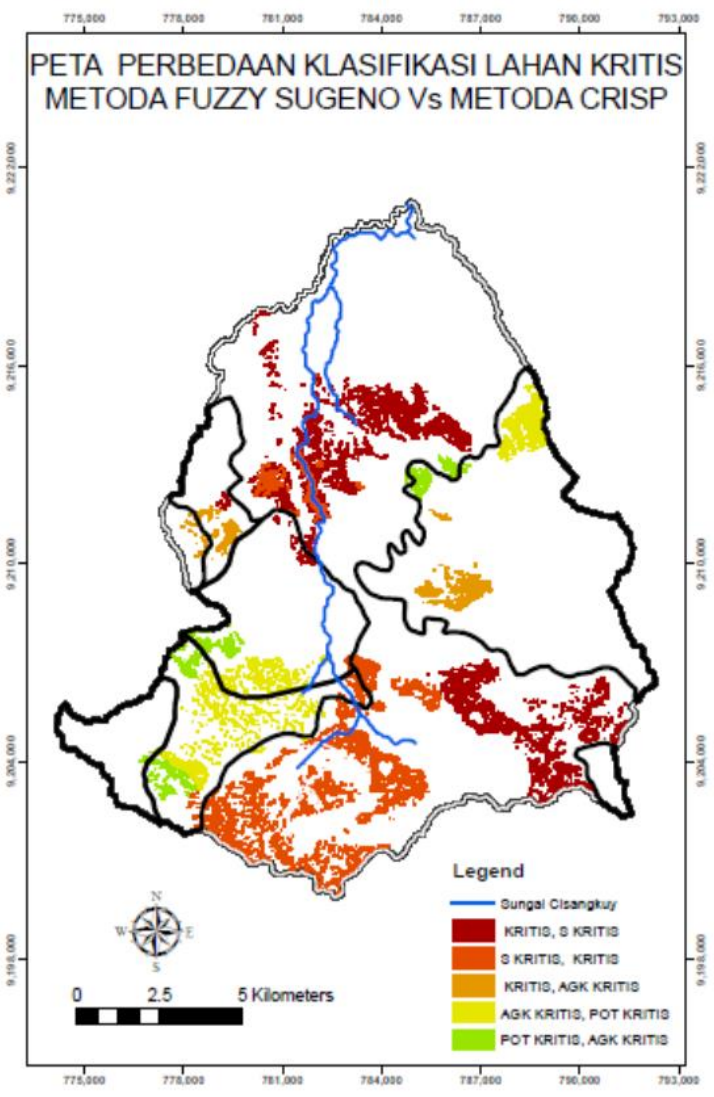

Gambar 8. Peta Perbedaan Klasifikasi Lahan Kritis Metoda Fuzzy Vs. Metoda Crisp

[3] Hall, G.B., F. Wang, Subaryono, 1992. Comparison of Boolean and fuzzy classification methods in land suitability analysis by using geographical information systems, Environment and Planning A. 24, pp. 497-516.

[4] Hasan M., A. Sapei, J. Purwanto, Sukardi, 2011, Kajian kebijakan pengelolaan sumber daya air pada daerah aliran sungai Citarum, Jurnal Sumber Daya Air. 7(2), pp. 105-118.

[5] Kastaman R., D.R. Kendarto, S. Nugraha, 2007. Penggunaan Metode Fuzzy Dalam Penentuan Lahan Kritis Dengan Menggunakan Sistem Informasi Geografis di Daerah SUBDAS Cipeles. Jurnal Teknotan. 1(2), pp. 1-11.

[6] Keshavarzi A., F. Sarmadian, A. Heidari, M. Omid, 2010 Land Suitability Evaluation Using Fuzzy Continuous Classification (A Case Study: Ziaran Region). Modern Applied Science. 4(7), pp. 72-81.

[7] Kumar S., A. Mishra, 2015. Critical Erosion Area Identification Base on Hydrological Response Unit Level for Effective Sedimentation Control in River Basin. Water Resource Management. 29(6), pp. 1749-1765.

[8] Kusumadewi, S., H. Purnomo, 2010, Aplikasi Logika Fuzzy Untuk Pendukung Keputusan. Graha Ilmu, Yogyakarta.

[9] Purwaamijaya, I.M., I. Widianingsih, 2013. Aplikasi GIS Untuk Pengelolaan Das Berkelanjutan Di Sub DAS Ciwidey Kabupaten Bandung, Kolokium Pengelolaan Sumberdaya Ait 2013, Puslitbang Sumber Daya Air, Badan Penelitian Dan Pengembangan Kementerian Pekerjaan Umum, Bandung.

[10] Prasetyo, S.Y.J., B.S. Hasiholan, Hartomo, P.K.D. Mila, B. Nuswantoro, 2013. Geographic Information System of Critical Level of Land Degradation (Critical Land) Based on Agro-ecological Zone (AEZ) in Agricultural Areas with Recombination Method of Fuzzy Logic and Scoring. International Journal of Computer Science Issues. 10(1), pp. 217-221. 